\title{
Kinematická analýza útočného úderu středem sítě ve volejbalu
}

\section{Kinematic analysis of attack hit of inside attacker's volleybal players}

\author{
František Zahálka ${ }^{1}$, Tomáš Malý', Miroslav Čada ${ }^{2}$, Lucia Malá $^{1}$ \\ Fakulta tělesné výchovy a sportu Karlovy univerzity, Praha ${ }^{1}$ \\ Fakulta sportovních studií Masarykovy univerzity, Brno ${ }^{2}$
}

\begin{abstract}
Abstrakt:
Cílem práce bylo porovnání a následné vyhodnocení útočného úderu středem sítě (zóna 3) v rüzných variantách provedení. Pro popis a vyhodnocení kinematiky pohybu byla použita metoda 3D kinematické analýzy. Sledovanou skupinou bylo 6 hráčů extraligové úrovně ve volejbalu mužu. Výsledkem analýzy byla deskripce jednotlivých fází a klíčových okamžiků techniky provedení. Dílčím cílem práce bylo prokázat vysokou intraindividuální stabilitu provedení jednotlivých hráčů vrcholové úrovně. Všichni sledovaní hráči prováděli útočný úder v modelové situaci vícekrát po sobě a pro analýzu byly subjektivně vybrány tři pokusy od každého hráče. Prokázalo se, že hráči vrcholové úrovně provádějící stejnou techniku mají vysokou interindividuální stabilitu provedení v klíčových fázích a momentech. Naměrené výsledky naznačují, že realizace uvedené herní činnosti vyžaduje vysoký stupeñ součinnosti útočicího a nahrávajícího hráče.
\end{abstract}

\begin{abstract}
:
Main work was kinematic analyse and resulting evaluation spike centre net (zone 3) in different variant fulfilment. Purposes were described, analyse and compare from kinematic of stand-point facture (techniques) spike from zone 3 with choice top players. In top fulfilment those techniques discovering at fulfilment spike same upper arm two diverse fulfilments running and rebound phase. Result analyse was comparative these two different technique fulfilment (spike upper arm with final step on opposite lower leg and in the second case spike upper arm with final step on concurrent lower leg as is attack arm). Particular purpose work was evidence high intra-individual stability fulfilment single players top levels of and subsequently describe inter-individuals characteristics players at different fulfilments.
\end{abstract}

Klíčová slova: volejbal, technika pohybu, kinematická analýza, útočný úder, výskok

Key words: $\quad$ volleyball, movement technique, kinematic analysis, spike, jump

Tato studie vznikla za podpory VZ MSM 0021620864 a GACR P407/11/P784.

\section{ÚVOD}

Volejbal je jedna z nejpopulárnějších her ve světě. Základní dovednosti, které se podílejí na hře, jsou podání, přihrávka, nahrávka, útok, blok, obrana v poli (herní činnosti) resp. výskok, agility (hbitost), flexibilita, rychlost reakce (pohybové schopnosti). Na hráče jsou kladeny vysoké požadavky na různé pohybové dovednosti a výkon je často závislý na individuálních skokanských schopnostech hráče (Tillman et al., 2004). Kugler et al. (1996) uvádějí, že elitní útočící hráči absolvující 16 až 20 tréninkových hodin týdně, ročně absolvují přibližně 40000 útočných úderů ve výskoku. Pro dosažení úspěchu ve volejbale jsou nutné silné a efektivní ofenzívní činnosti a smeč je považován za hlavní formu útoku (Coleman et al., 1993). $Z$ uvedených důvodů je ve vědeckých studiích značná pozornost věnována právě útočnému úderu, který se zkoumá z různých pohledů. Forthomme et al. (2009) prezentují faktory korelující s rychlostí útočného úderu u hráčů. Rozdíly v kinematických ukazatelích mezi symetrickým (CMJ - Counter Movement Jump) a asymetrickým SJ (spike jump) byly prezentovány v studii Wagner et al. (2009). Tilp et al. (2008) popisují rozdíly $\mathrm{z}$ biomechanického hlediska $\mathrm{v}$ realizovaném pohybu mezi útočným úderem u volejbalistů a beachvolejbalistů. Sledováním účinnosti různých postupů pro zlepšení výšky výskoku 
při útoku se zabývají např. Newton et al. (1999), Reeberg et al. (2008), Sheppard et al. (2008), Sheppard et al. (2009) a další.

Některé studie se zabývají jenom dopadem hráče po útočném úderu, a to hlavně ze zdravotního hlediska (Tillman et al., 2004, Bisseling et al., 2008, Cronin et al., 2008, Marquez et al., 2009). Komplexnější kinematickou analýzu útočného úderu s využitím sledování parametrů inverzní dynamiky popisují Wagner et al. (2009).

Většina výzkumných studií je realizována na útočném úderu ze zóny II resp. IV. Protože je v moderním volejbalu nutné, aby se do útočné fáze zapojil co nejvyšší počet hráčů, musí se využívat i další alternativy útoku z jiných zón. Jednou z možností je tzv. útok středem, který je nejrychlejším útokem, at již před nebo za nahrávače. Je proto nezbytné, aby se blokující hráč „vyvěsil” (pohybově reagoval) současně s útočníkem. V opačném př́ipadě je možnost zabránit účinnosti útoku minimální. Většinou se jedná o ú1 (rychlík před $\mathrm{N})$, ú4 (1,5 m od N) a ú3 (rychlík za N), výjimečně ú7 a ú8. Při všech útocích prvního sledu hráč nečasuje rozběh dle nahrávky, ale podle přihrávky nahrávači. Efektivní útok středem se dá hrát pouze po výborné př̀hrávce (do $2 \mathrm{~m}$ od sítě), je nezbytně nutná maximální sehranost útočníka a nahrávače. Pokud nahrávač hraje středem málo, at už z důvodu nesehranosti nebo malé důvěry v útočníka, je obrana mnohem jednodušší a zejména v koncovkách setů a zápasů může být rozhodujícím faktorem při utkání. Cílem předložené studie je identifikovat a analyzovat časově-prostorové charakteristiky pohybu volejbalistů při útoku středem sítě.

\section{METODIKA}

Výzkumný soubor tvořili hráči (3 blokaři, 3 útočící hráči) vrcholové úrovně mužské kategorie hrající nejvyšší českou volejbalovou ligu $(n=6$, věk $=23,7$ let, tělesná výška $=195,6 \pm 8,5 \mathrm{~cm}$, tělesná hmotnost $=87,9 \pm 7,5 \mathrm{~kg}$ ). Pro analýzu pohybu byla použita kinematická analýza. Měření bylo prováděno v modelové herní situaci, kde hráč stál cca $4 \mathrm{~m}$ od sítě v zóně III a smečoval nahrávku č. 5. („metr“). Nahrávač stál na středu hřiště v blízkosti sítě, kde připravoval stejné nahrávky všem útočícím hráčům (Obr. 1). Měření probíhalo na odpoledním tréninku po standardním rozcvičení ( 20 min bez míče, 10 min ve dvojicích s míčem, 15 min rozsmečování). Použity byly míče Gala Pro-line BV 5591 S. Pro záznam pohybu byly použity tř̀i statické videokamery SONY HDR-HC9E (SONY CORPORATION ^, Japan) se snímkovací frekvencí 50 půlsnímků za sekundu, snímaný prostor byl kalibrován 4m kvádrem se 16 kalibračními body. Pro výpočet prostorových souřadnic byla použita metoda DLT (Direct Linear Transformation) a vyhodnocovací software TEMA Bio 2.3 (Image Systems AB, Sweden). Snímaný prostor byl v rozsahu $5 \mathrm{~m}$ od sítě a chyba rekonstrukce byla vypočtena $0,025 \mathrm{~m}$, což reprezentuje $0,5 \%$ velikosti snímaného prostoru. Na těle sledované osoby byly vybrány významné body a zkonstruován drátový model, z kterého bylo vypočteno těžiště těla (Obr. 2).

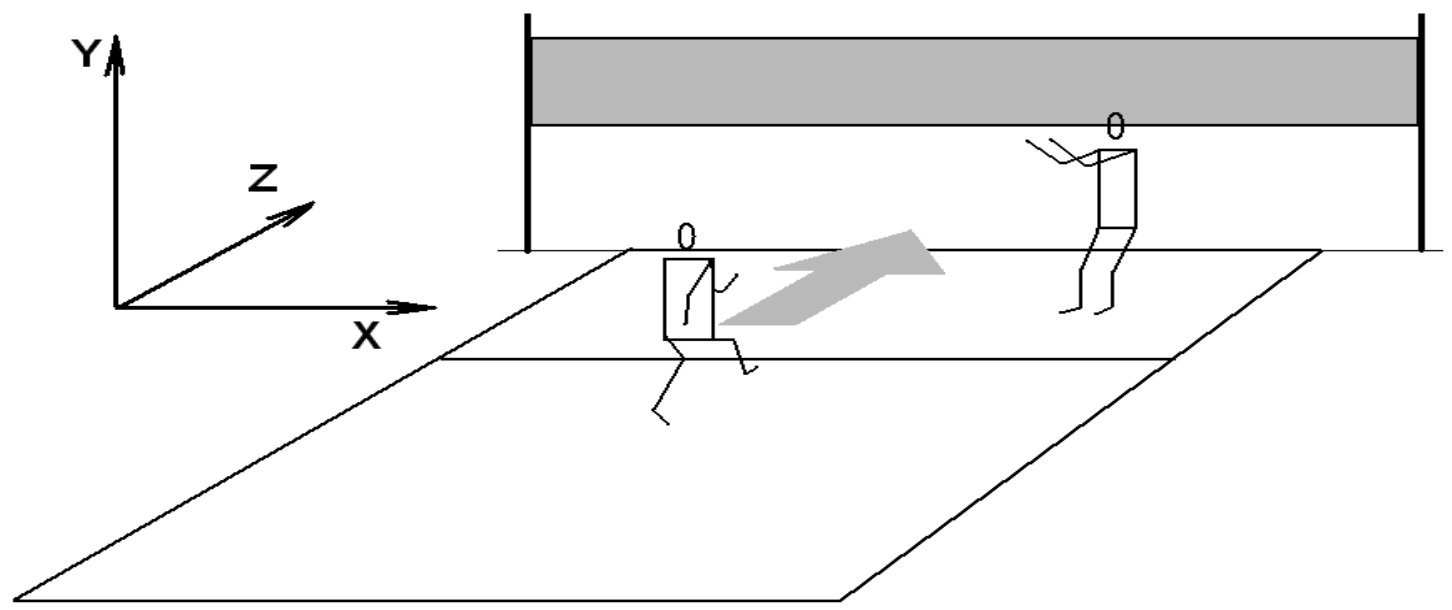

Obrázek 1. Schematické znázornění hřiště a zavedený souřadný systém. 


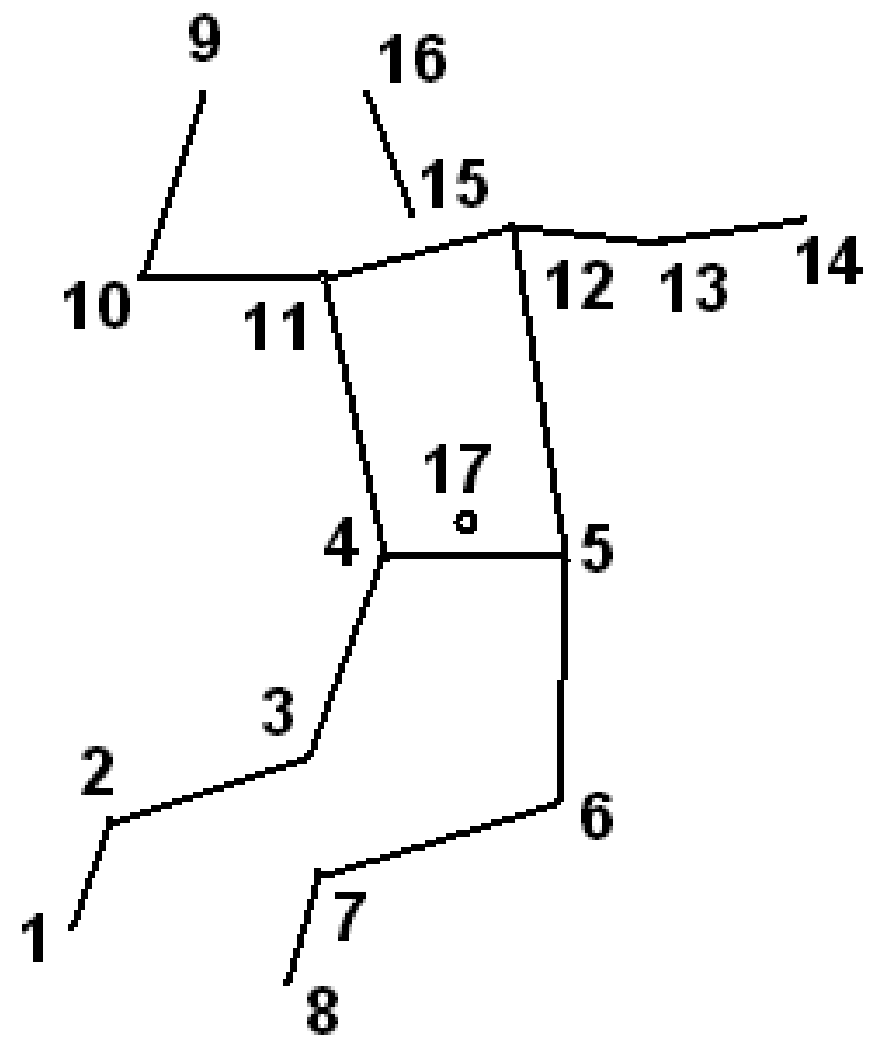

1. Pravá špička

2. Pravý kotník

3. Pravé koleno

4. Pravý bok

5. Levý bok

6. Levé koleno

7. Levý kotník

8. Levá špička

9. Pravé zápěstí

10. Pravý loket

11. Pravé rameno

12. Levé rameno

13. Levý loket

14. Levé zápěstí

15. Brada

16. Čelo

17. Těžiště těla

Obrázek 2. Vybrané body na těle osoby a těžiště těla

Pro celý pohybový cyklus byly stanoveny jednotlivé fáze a kritická místa, podle nichž se provádělo srovnávání jednotlivých pokusů: startovní postoj (poloha těla na začátku rozběhu), nejdelší krok (nejdelší vzdálenost chodidel), dokrok (poslední krok rozběhu), úder do míče (smeč) a dopad (kontakt obou chodidel s podložkou). Pro porovnání hráčů mezi sebou (interindividuální stabilita) byly hodnoceny parametry samotného rozběhu (délka krokủ, dopředná a vertikální rychlost) i parametry odrazu (místo odrazu, natočení dolních končetin a trupu směrem $\mathrm{k}$ síti). $\mathrm{V}$ rámci hodnocení stability pohybového stereotypu byly hodnoceny tř̀i pokusy každého hráče.

\section{VÝSLEDKY A DISKUSE}

Prvním klíčovým bodem je startovací postoj. Kolena mírně pokrčená, váha je rozložena na obou dolních končetinách, hráč stojí a zahajuje pohyb vpřed. Levá noha je v mírném výkroku pro lepší stabilitu těla. Paže jsou mírně pokrčeny v loktech (ruce před tělem). Při zahájení pohybu je hráč vzdálen od sítě cca $4 \mathrm{~m}$, tj. asi $1 \mathrm{~m}$ před útočnou čarou, vzdálenost chodidel resp. kotníků dolních končetin je $0,6-0,7 \mathrm{~m}$. 

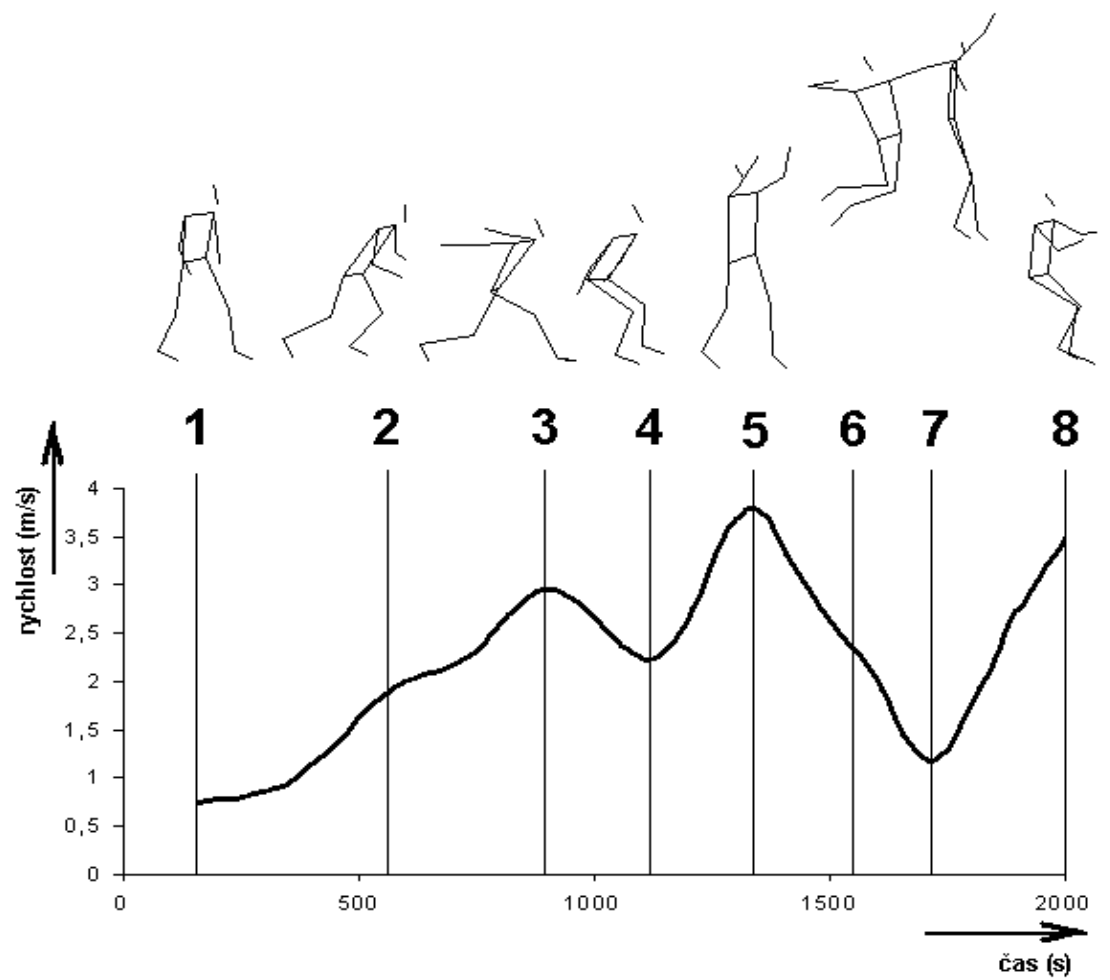

Obrázek 3. Průběh rychlosti těžiště těla v průběhu pohybu s rozdělením na fáze

Dalším klíčovým okamžikem je nejdelší krok rozběhu (Obr. 4). Hráč vyráží vpřed pravou dolní končetinou a první krok má za cíl získat co nejvyšší dopřednou rychlost. U tř́krokového rozběhu je to krok druhý s pravou dolní končetinou vpředu. O kroku hovoříme i přesto, že okamžik nejdelší vzdálenosti dolních končetin je v krátké letové fázi, kdy se hráč nedotýká žádnou dolní končetinou země.

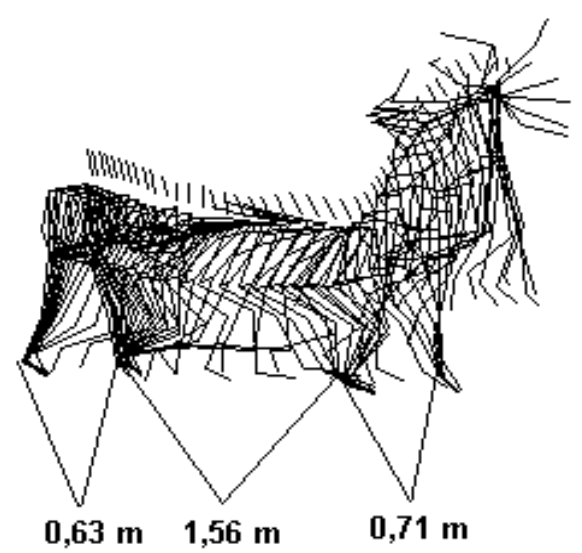

Obrázek 4. Kinogram pohybu s délkou jednotlivých kroků

Název „nejdelší krok“ reprezentuje nejdelší vzdálenost levého a pravého kotníku. Horní končetiny jsou v maximální poloze zapažení vzad povýš. Celková vzdálenost, kterou hráč urazí během rozběhu, je cca $2,25 \mathrm{~m}$. Přestože se hráč pohybuje přímo vpřed, vykoná během rozběhu stranový pohyb cca $0,25 \mathrm{~m}$ 
v levém směru $\mathrm{z}$ pohledu směrem $\mathrm{k}$ síti. To je $\mathrm{z}$ důvodu došlapu na levou nohu a vytočení trupu na pravou stranu směrem k nahrávači. Při pohybu vpřed se během prvního a druhého kroku tělo snižuje ve vertikálním směru až do své dolní úvratě, které je docíleno před došlapem třetího kroku.

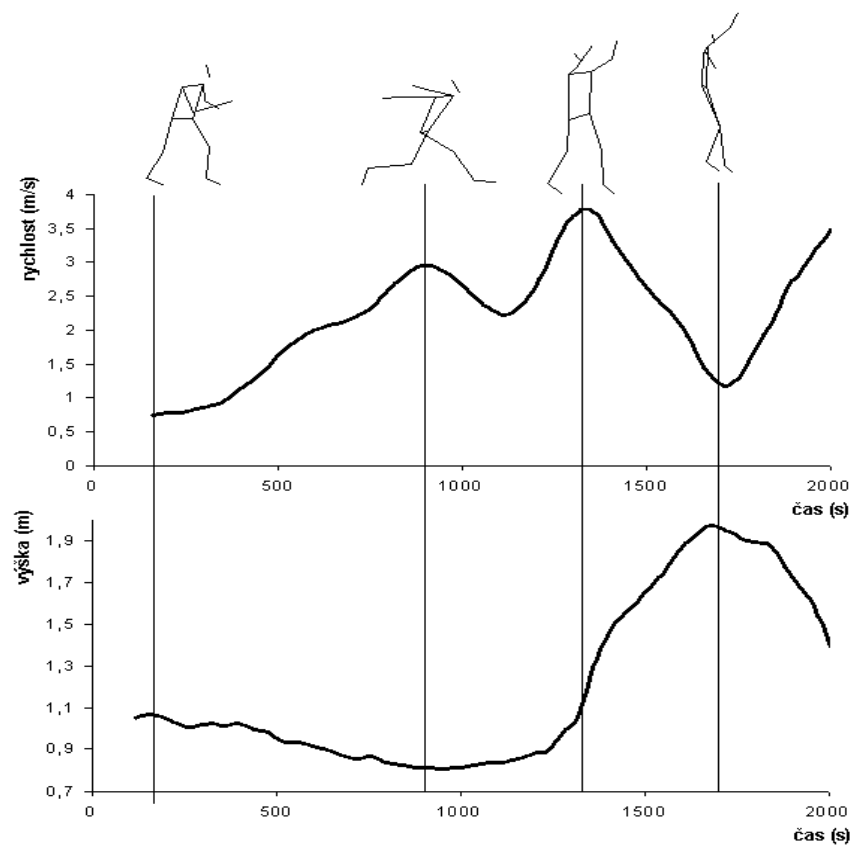

Obrázek 5. Trajektorie těžiště těla ve vertikálním směru a rychlost těžiště těla během pohybu

$\mathrm{Na}$ Obr. 5 je znázorněna vertikální změna polohy těžiště těla v průběhu celého pohybu spolu se změnou celkové rychlosti. Od počátku pohybu se těžiště těla sníží do nejnižší polohy o cca $0,25 \mathrm{~m}$, ze které se do okamžiku vzletu (poslední kontakt dolních končetin s podložkou) zvýší o cca $0,5 \mathrm{~m}$. Od tohoto okamžiku začíná letová fáze, v horní úvrati letu je těžiště těla zvýšeno cca o $0,8 \mathrm{~m}$ oproti výchozí pozici, ve která hráč pohyb začínal.

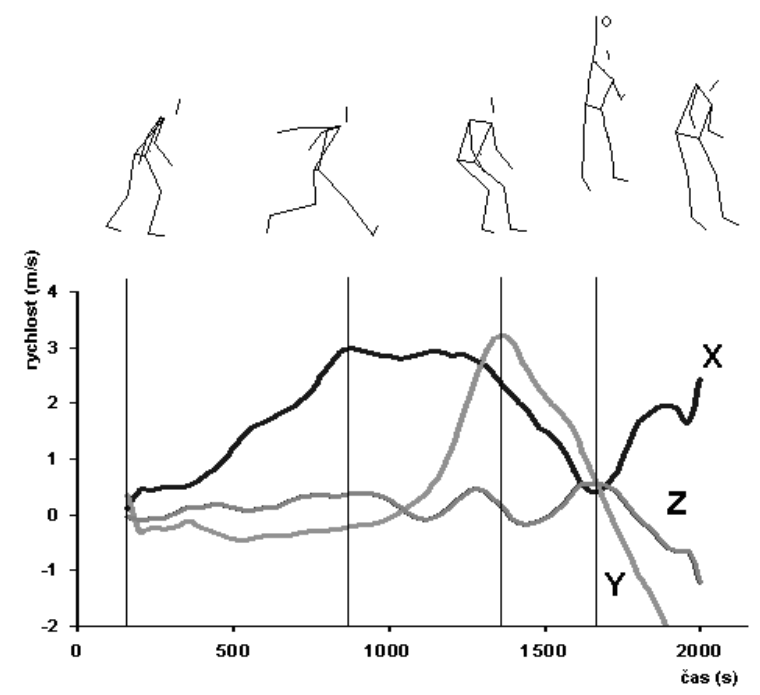

Obrázek 6. Rychlost pohybu těžiště v jednotlivých složkách 
Rychlost pohybu těžiště těla hráče lze popsat ve třech osách (Obr. 6). Osa X reprezentuje pohyb vpřed směrem k síti, osa Y pohyb vertikální (snížení a zvýšení těla těžiště těla) a osa $\mathrm{Z}$ pohyb transverzální (pohyb do stran). Tato složka se na celkové rychlosti podílí nejméně a změny jsou patrné až před došlapem, kdy dochází k natočení boků a ramen před výskokem, a tím i k vyššímu pohybu do strany. Největší změna rychlosti v ose $\mathrm{Z}$ je pak především po úderu do míče, kdy dochází $\mathrm{k}$ výrazné rotaci trupu ve směru úderové paže.

Dokrok je další klíčová fáze. Je to okamžik, kdy hráč dokročí levou dolní končetinou před pravou v posledním kroku rozběhu. Špička levé nohy je mírně stočena dovnitř před pravou končetinu. Postavení dolních končetin je výchozím předpokladem pro efektivní rotaci trupu $\mathrm{v}$ př́pravné fázi smeče, kdy pohyb vychází $\mathrm{z}$ distálních částí dolních končetin do boků a přes páteř se přenáší do ramen a následně do distálních částí končetin horních. Tím se významně podílí na práci švihové paže. V tomto okamžiku dochází k transformaci horizontální na vertikální energii, kdy hráč přeměňuje rychlost získanou rozběhem na zvýšení výskoku. Jak již bylo řečeno, rozběh slouží k získání dostatečné dopředné rychlosti, která musí být v následném krátkém okamžiku dokroku snížena a je jí využito pro zvýšení energie vertikální tak, aby bylo dosaženo co nejvyššího výskoku. Při porovnání horizontální a vertikální složky rychlosti těla hráče je od okamžiku kontaktu dolní končetiny při dokroku až do kulminace letové fáze vidět prudký pokles horizontální složky rychlosti těla a prudký nárůst složky rychlosti vertikální. Maximální vertikální rychlosti těla je dosaženo v horní úvrati letu. $\mathrm{V}$ tom okamžiku dosahuje horizontální složka svého lokálního minima a v dalším okamžiku začne narůstat, což je zapř́íčiněno mohutným švihem smečující horní končetiny s doprovodným pohybem trupu a hlavy. Rychlost rozběhu je limitována maximální hodnotou, kdy je hráč schopen maximální část energie transformovat do výskoku a při následném pohybu dokáže dopředný pohyb zastavit v souladu s pravidly bez kontaktu se sítí.

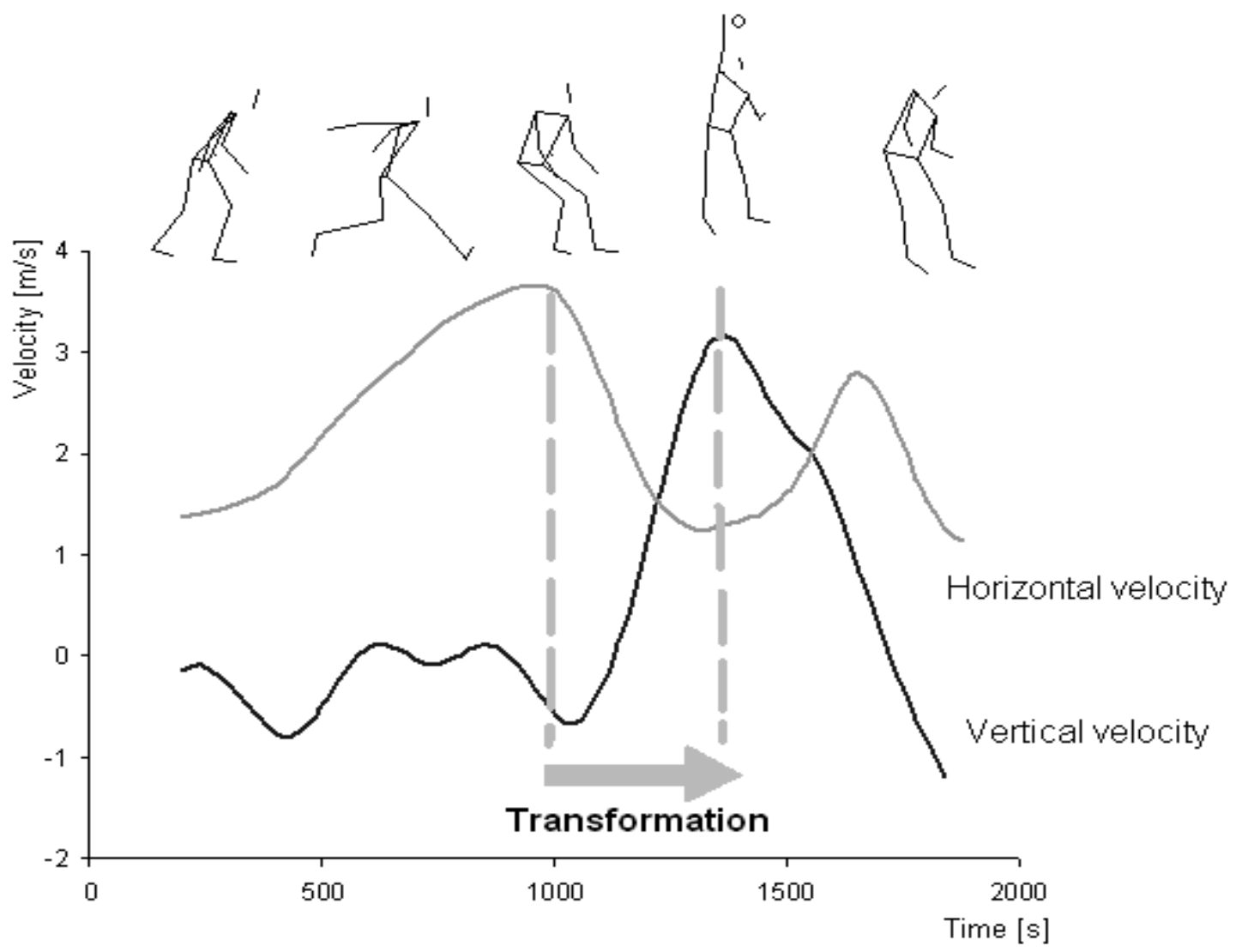

Obrázek 7. Transformace horizontálního impulzu na vertikální 
Jednotlivé fáze jsou spolu s průběhy vertikální a horizontální rychlosti těla znázorněny na Obr. 7 . K obrázku je zapotřebí vysvětlit, že záporné hodnoty vertikální složky rychlosti představují pohyb těla vzhưru a dolů, rychlost je vždy pouze kladná, ale záporné znaménko zde znázorňuje její orientaci. V časovém úseku $\mathrm{t}=920-1200 \mathrm{~ms}$ klesne dopředná rychlost hlavy z maximální hodnoty cca 3,5 m.s ${ }^{-1}$ na lokální minimální hodnotu $1 \mathrm{~m} \cdot \mathrm{s}^{-1}$ (rozdíl 2,5 m.s $\mathrm{s}^{-1}$ ). Oproti tomu vzroste vertikální hodnota rychlosti z lokálního minima $0,8 \mathrm{~ms}^{-1} \mathrm{v}$ opačném směru na maximální hodnotu $3 \mathrm{~m} \cdot \mathrm{s}^{-1}$ (rozdíl $3,8 \mathrm{~m} \cdot \mathrm{s}^{-1}$ ). Je vhodné upozornit, že doba transformace trvá cca $280 \mathrm{~ms}$ a rozběh do okamžiku smeče něco málo přes 1 sekundu, celý pohybový cyklus včetně dopadu a stabilizace necelé dvě sekundy.

Velice důležitým prvkem pro efektivní realizaci smeče je švih smečující paže, který vychází z rotace trupu. Pohybová realizace vychází z postavení distálních částí dolních končetin při kontaktu s podložkou, přes které se rotace dostává na boky, přes trup na ramena, a jejich pohyb pak determinuje pohyb končetin horních. Lze popsat postavení a změnu polohy osy boků a ramen v jednotlivých fázích pohybu smečaře (Obr. 8).

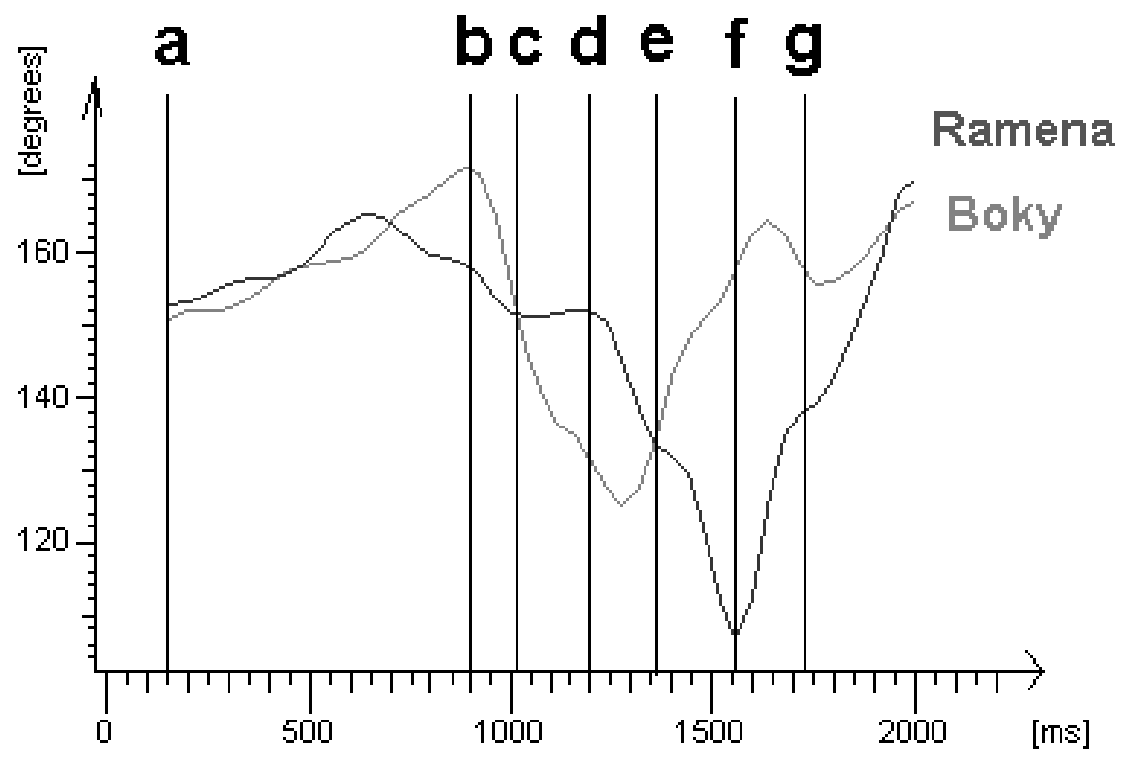

Obrázek 8. Průběh změny úhlů v ose boků a ramen

Ve výchozím postavení jsou úhly boků a ramen vůči síti takřka shodné cca $150^{\circ}$. Po výkroku pravou DK se během nejdelšího kroku úhly mění, boky dosahují svého maxima $171^{\circ}$ (jsou skoro rovnoběžně se sítí) a ramena v tomto okamžiku mají hodnotu $158^{\circ}$ (na grafu bod b). V následujícím okamžiku došlapuje pravá dolní končetina na podložku, poloha boků i ramen je vůči síti téměř shodná (Obr. 9) a hodnota je $150^{\circ}$ (na grafu bod c). Až do došlapu na obě dolní končetiny zůstává úhel v ramenou stejný $150^{\circ}$ a rotace probíhá pouze v dolní části těla, kdy se boky dostávají na hodnotu $130^{\circ}$ (na grafu bod d). Po došlapu se tělo hráče zdvihá a začíná opačná rotace boků a ramen. Boky se z maximálního vytočení od sítě $\left(125^{\circ}\right)$ otáčejí zpět a ramena pokračují v opačné rotaci oproti bokům. Shodného úhlu boků a ramen $133^{\circ}$ je dosaženo při posledním kontaktu dolních končetin s podložkou (na grafu bod e). Boky se poté stáčejí dále k síti a vytvářejí předpětí pro rotaci horní části těla. Ramena se vytáčejí od sítě až do okamžiku maximálního nápřahu smečující paže, kdy je úhel v ramenou $105^{\circ}$ a úhel v bocích $157^{\circ}$ (na grafu bod f). Osa ramen po maximálním nápřahu rotuje směrem $\mathrm{k}$ síti a jejich úhel je $\mathrm{v}$ okamžiku úderu $137^{\circ}$, boky mají opět hodnotu $157^{\circ}$, ale mezitím vykonaly rotační pohyb o cca $10^{\circ}$ směrem k síti (na grafu bod $\mathbf{g}$ ). Po kontaktu s míčem pokračuje rotace ramen i boků v směru pohybu až do dopadu. 


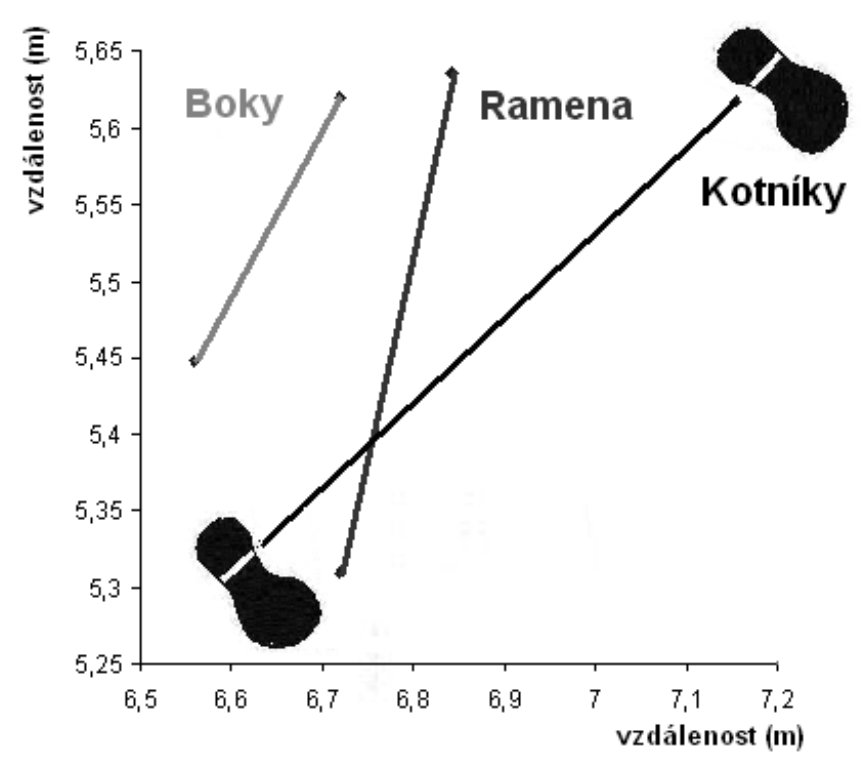

Obrázek 9 . Uhel spojnic špiček dolních končetin, boků a ramen při odrazu

Významným klíčovým okamžikem je úder do míče, kdy se vytažená paže dostává do kontaktu s míčem. $\mathrm{V}$ ideálním př́padě je to $\mathrm{v}$ horní úvrati letové dráhy těla. $\mathrm{V}$ době kontaktu jsou dolní končetiny v prodloužení trupu až s mírnou flexí v koleních kloubech. Posledním klíčovým okamžikem je dopad, což je okamžik, kdy se hráč dotkne oběma nohama podložky. Hráč dopadá přes špičky postupně nejprve na levou dolní končetinu a pak na pravou. Dopad přes špičky s mírnou flexí v kolenou je velmi důležitý z hlediska tlumení dopadu. Z hlediska provedení smeče je dopad nepodstatný, ale poloha těla ukazuje zvládnutí letové fáze. Od okamžiku opuštění podložky už žádnou další energii hráč získat nemůže, a musí s ní efektivně hospodařit. Všechny pohybové činnosti mimo připravovaný úder do míče mají za následek ztrátu energie a všechny korekční pohyby během letové fáze se odrazí v poloze těla a končetin během dopadu.

Hráči vykazovali vysokou intraindividuální techniku provedení útočného úderu. Při porovnání absolutních hodnot $\mathrm{v}$ kritických místech a při porovnání průběhu změn v jednotlivých fázích se prokázalo, že hráči mají pohybový stereotyp vysoce stabilní. Vysokou stabilitu provedení smečovaného podání u elitních hráčů uvádějí Lehnert, Janura \& Stromšík (2003). Tady se pochopitelně výrazně projevuje somatotyp hráče, vyšší hráč má delší krok, a tím jiný výběr místa rozběhu a odrazu apod.
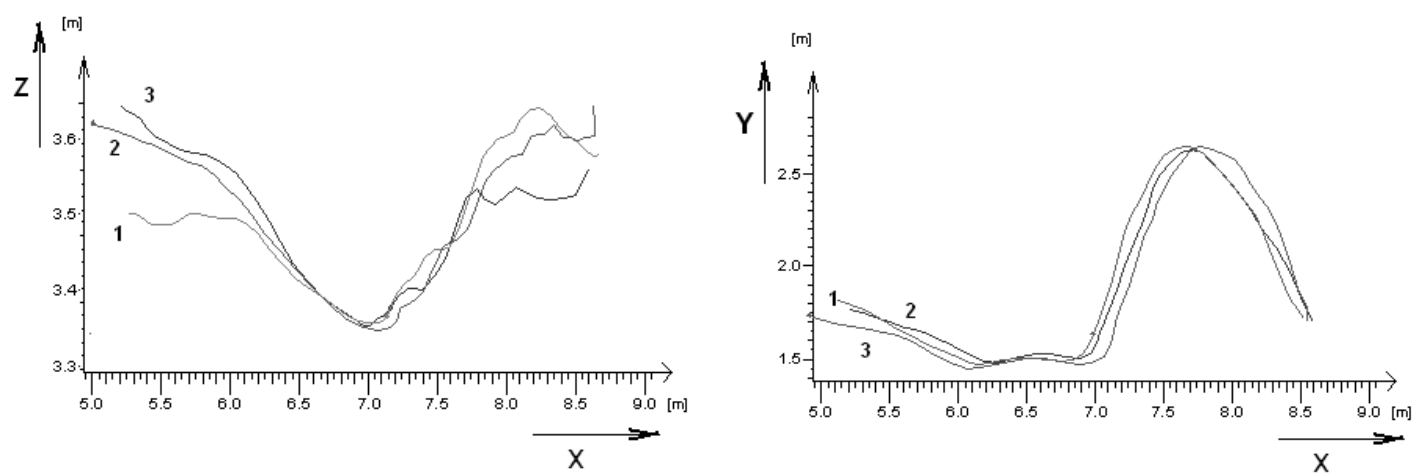

Obrázek 10. Trajektorie těžiště těla v rovině XZ (pohled shora) a v rovině XY (pohled zboku) u jednoho hráče během tři pokusů 
$\mathrm{Na}$ Obr. 10 jsou znázorněny trajektorie tří pokusů jednoho hráče v rovině XZ (při pohledu shora) a v rovině XY (při pohledu zboku). Při hodnocení intraindividuální stability je potřeba vzít v úvahu, že bod výchozího postavení během startovacího postoje se ve vzdálenosti $\mathrm{k}$ síti liší cca o $0,30 \mathrm{~m}$ a v bočním směru o $0,17 \mathrm{~m}$. Největší stranová výchylka je okolo pozice $2 \mathrm{~m}$ od sítě, kdy dochází k př̀enesení hmotnosti těla během jednooporové fáze pravé dolní končetiny. Při odečtení konkrétních hodnot je boční výchylka těžišš $0,31 \mathrm{~m}$.

\begin{tabular}{|c|c|c|c|c|}
\hline & P-P1 & L-L1 & PL & odraz \\
\hline Pokus 01 & 2,39 & 2,27 & 3,12 & 0,72 \\
\hline Pokus 02 & 2,62 & 2,24 & 3,01 & 0,58 \\
\hline Pokus 03 & 2,32 & 2,28 & 2,93 & 0,67 \\
\hline průměr & $\mathbf{2 , 4 4}$ & $\mathbf{2 , 2 6}$ & $\mathbf{3 , 0 2}$ & $\mathbf{0 , 6 6}$ \\
\hline var & $\mathbf{0 , 3 1}$ & $\mathbf{0 , 0 4}$ & $\mathbf{0 , 1 9}$ & $\mathbf{0 , 1 4}$ \\
\hline
\end{tabular}

Tabulka 1. Délky kroků jednoho hráče př̀i třech rozbězích.

\begin{tabular}{|c|c|c|c|c|}
\hline & P-P1 & L-L1 & PL & odraz \\
\hline Hráč 01 & 2,44 & 2,26 & 3,02 & 0,66 \\
\hline Hráč 02 & 2,53 & 2,48 & 3,21 & 0,61 \\
\hline Hráč 03 & 2,38 & 2,29 & 3,42 & 0,55 \\
\hline Hráč 04 & 2,98 & 2,5 & 3,51 & 0,73 \\
\hline Hráč 05 & 3,01 & 2,62 & 3,38 & 0,65 \\
\hline Hráč 06 & 2,59 & 2,21 & 3,09 & 0,64 \\
\hline průměr & $\mathbf{2 , 6 6}$ & $\mathbf{2 , 3 9}$ & $\mathbf{3 , 2 7}$ & $\mathbf{0 , 6 4}$ \\
\hline var & $\mathbf{0 , 6 3}$ & $\mathbf{0 , 4 1}$ & $\mathbf{0 , 4 9}$ & $\mathbf{0 , 1 8}$ \\
\hline
\end{tabular}

Tabulka 2. Průměrné délky kroků při třech rozbězích u celé skupiny hráčů.

Legenda:

P-P1 - vzdálenost mezi výkrokem a dokrokem pravé dolní končetiny

L-L1 - vzdálenost mezi výkrokem a dokrokem levé dolní končetiny

P-L - vzdálenost mezi výkrokem pravé dolní končetiny a dokrokem levé dolní končetiny

Odraz - vzdálenost mezi dolními končetinami při odrazu.

Tabulka 1 srovnává průměry jednotlivých kroků všech hráčů provádějících rozběh. Délka druhého kroku je u všech hráčů nejdelší. Ukazuje se, že při rozběhu je důležitost přemístění hráče od startovní pozice až do pozice odrazu záležitostí posledních dvou kroků.

Dalším sledovaným parametrem je rychlost přesunu, kterou hráči dosahují v popisovaných krocích jednotlivých klíčových fází. Hráči se rozbíhají v prvním kroku rychlostí cca 2,55 $\mathrm{m} \cdot \mathrm{s}^{-1}$, kterou udrží a mírně navýší v druhém kroku. Dopředná rychlost se po odrazu u hráčů sníží na $1,71 \mathrm{~m} \cdot \mathrm{s}^{-1}$. Letová fáze je velice podobná u všech hráčủ. Polohy těla a dolních končetin se mírně liší v časovosti dopadu dolních končetin a v natočení trupu. To úzce souvisí s místem $\mathrm{v}$ soupeřově poli, kam smečař umístil míc. Tento parametr nebyl ve studii zvlášt' hodnocen a hráči bez postavené obrany na síti mohli útočit podle vlastní volby.

Maximální velikost vertikální rychlosti je u skupiny hráčů velmi podobná (2,91-ej2,96 m.s $\left.{ }^{-1}\right)$. Lze předpokládat, že se hráči odrážejí stejnou rychlostí a i dopad je z časového hlediska velmi podobný. Významnou fází je tedy samotný rozběh. U hráčů dochází ke snížení těžiště těla během dvou prvních kroků a při třetím, nejdelším kroku se po okamžiku dokroku tělo plynule připravuje na vlastní odraz. 


\section{ZÁVĚR}

Hráči elitní úrovně mají vysokou intraindividualitu provedení útočného úderu středem. Hráči elitní úrovně, provádějící stejnou techniku, mají vysokou interindividuální stabilitu provedení v klíčových fázích a momentech. To lze vysvětlit především snížením variability možných řešení daného pohybu, který musí být realizován za velmi krátkou dobu a v relativně malém prostoru. Na rozdíl od útoku vedeného $\mathrm{z}$ kůlu (z2, resp. z4), kde je rozběh mnohem delší, může být prováděn $\mathrm{v}$ různých směrech a vzhledem $\mathrm{k}$ nezbytnosti řešení útočného úderu k očekávané obranné pozici bloků musí zůstat variace pro umístění míče do volného směru do soupeřova pole. Oproti tomu se při útoku středem hráči rozebíhají velmi přímočaře k nahrávači. Urazí kratší vzdálenost oproti útoku z krajních zón a i jejich stranová výchylka ve transverzálním směru je výrazně menší. Startovní postoj je 1-1,5 m od čáry označující útočné pole (4 - 4,5 m od sítě), což je opět oproti útoku z krajních zón výrazně blíže k síti. Volejbalový rozběh od startovní pozice až po dopad je kratší a pomalejší než u hráčů u útočících z krajních zón. Nižší rychlost rozběhu je podmíněna i tím, že při př́mém rozběhu musí hráč po dopadu minimalizovat dopředný pohyb a zastavit v souladu s pravidly před sítí. Při náběhu na kůlu více ze strany je maximální rychlost navýšena právě o transverzální složku. Hráč se při letu a dopadu nepohybuje tak přímočaře $\mathrm{k}$ síti.

\section{LITERATURA}

BISSELING, R.W., HOF, A.L., BREDEWEG, SW., ZWERVER, J., MULDER, T. (2008). Are the take-off and landing phase dynamics of the volleyball spike jump related to patellar tendinopathy? British Journal of Sports Medicine, 42(6), 483.

COLEMAN, S.G.G., BENHAM, A.S., NORTHCOTT, S.R. (1993). A three-dimensional cinematographical analysis of the volleyball spike. J Sports Sci. 11, 295-302.

CRONIN, J.B., BRESSEL, E., FINN, L. (2008). Augmented Feedback Reduces Ground Reaction Forces in the Landing Phase of the Volleyball Spike Jump. Journal of Sport Rehabilitation, 17, 148-159.

FORTHOMME, B., CROISER, J.L., CICERONE, G., CRIELAARD, J.M., CLOES, M. (2009). Factors correlated with volleyball spike velocity. The American Journal of Sports Medicine, 33(10), 1513-1519.

KUGLER, A., KRÜGER-FRANKE, M., REININGER, S., TROUILLIER, H.H., ROSEMEYER, B. (1996). Muscular imbalance and shoulder pain in volleyball attackers. Br J Sports Med., 30, 256-259

LEHNERT, M., JANURA, M., STROMSIK, P. (2003). The jump serve of the best servers on the Czech national men's volleyball team. International Journal of Volleyball Research, 6(1), 10-13.

MARQUEZ, W.Q., MASUMURA, M., AE, M. (2009). The effects of jumping distance on the landing mechanics after volleyball spike. Sports Biomechanics, 8(2), 154-166.

NEWTON, R.U., KRAEMER, W.J., HÄKKINEN, K. (1999). Effects of ballistic training on preseason preparation of elite volleyball players. Medicine and Science in Sport and Exercise, 31(2), 323-330.

REEBERG, L.C., DOURADO, A.C., ONCKEN, P., MANCAS, S., DA COSTA, S.C. (2008). Adaptations on jump capacity in Brazilian volleyball players prior to the under-19 World Championship. Journal of Strength and Conditioning Research, 22(3), 741-749.

SHEPPARD, J.M., NEWTON, R.U., MCGUIGAN, M.R. (2008). The effect of depth-jumping on vertical jump performance of elite volleyball players: An examination of the transfer of increased stretch-load tolerance to spike jump performance. Journal of Australian Strength \& Conditioning, 16(4), 3-11.

SHEPPARD, J.M., CHAPMAN, D.W., GOUGH, C., MCGUIGAN, M.R., NEWTON, R.U. (2009). Twelve-month training-induced changes in elite international volleyball players. Journal of Strength and Conditioning Research, 23(7), 2096-2101.

TILLMAN, M.D., HAAS, C.J., BRUNT, D., BENNETT, G.R. (2004). Jumping and landing techniques in elite women's volleyball. Journal of Sports Science and Medicine, 3, 30-36.

TILP, M., WAGNER, H., MILLER, E. (2008). Difference in 3D kinematics between volleyball and beach volleyball spike movements. Sports Biomechanics, 7(3), 386-397.

WAGNER, H., TILP, M., VON DUVILLARD, S.P., MUELLER, E. (2009). Kinematic Analysis of Volleyball Spike Jump. International Journal of Sports Medicine, 30(10), 760-766. 